LETTER TO THE EDITORS

\title{
VARIATIONS IN THE AMBIENT OZONE CONCENTRATION DURING THE 26 FEBRUARY 1979 SOLAR ECLIPSE*
}

\author{
(First received 5 October 1979 and in final form 22 February 1980)
}

\begin{abstract}
The ambient ozone concentration was measured during the partial solar eclipse on 26 February 1979, at Argonne National Laboratory. A $50 \%$ reduction in the ozone concentration occurred during the eclipse as a result of photochemical reactions. The observed lag time between the minima of the solar radiation and the ozone concentration is consistent with the computed lag time. The labile nature of ozone is self-evident in what may be the first measurement of the ambient ozone concentration during a solar eclipse.
\end{abstract}

\section{INTRODUCTION}

Measurements of ambient ozone concentration made at Argonne National Laboratory often show effects of photochemical reactions involving primary pollutants. Argonne is occasionally affected by pollutants that are transported from the industrial areas in northwest Indiana and Chicago, located about $50 \mathrm{~km}$ to the east and northeast and from a major interstate highway $2 \mathrm{~km}$ to the north. Decreases in the ozone concentration frequently occur when Argonne lies downwind of one of these major pollution sources, but when wind speeds are low, increases in the ozone concentration are observed (Davis et al., 1974; Dimitriades, 1977; Leighton, 1961; Miller et al., 1978). These observations, however, appear relatively insignificant when compared with the data obtained on 26 February 1979, when a partial solar eclipse (approx $80 \%$ of totality) provided an opportunity to observe the strlkingly dynamic nature of ozone photochemistry.

\section{OBSERVATIONS AND CALCULATIONS}

A MeMillan Model 1100 chemiluminescent ozone sensor is used routinely to monitor the ambient ozone concentration at a height of $3.7 \mathrm{~m}$. The sensor's lag time plus the time required for a $90 \%$ response to an imposed change in the ozone concentration is less than $10 \mathrm{~s}$; the lag time arises from the transit time in the Teflon sampling tube. Total solar radiation is measured nearby with an Eppley pyranometer.

During the daylight hours of 26 February, the wind direction was north to north-northeast at speeds between 4 and $8 \mathrm{~m} \mathrm{~s}^{-1}$. Nephelometer data indicate that the $b_{\text {scat }}$ values were less than $1 \times 10^{-5} \mathrm{~m}^{-1}$ until the late afternoon. Thus, no significant sources of pollution lay immediately upwind and pollution levels were low. About one hour after sunrise, the sun passed behind clouds, as can be seen in Fig. 1, and remained partially obscured for almost two hours. By 0915 CST the sky was practically clear and remained so throughout the remainder of the day. The eclipse began, reached a maximum, and ended at about 0936, 1052, and 1210 CST, respectively.

Figure 1 shows changes in total (direct plus diffuse) insolation and ozone concentration measured during the eclipse. The decrease in radiation follows the anticipated form. The changes in the ozone concentrations can be explained by examining the three fastest reactions involving nitric oxide (NO), ozone $\left(\mathrm{O}_{3}\right)$, and nitrogen dioxide $\left(\mathrm{NO}_{2}\right)$ (Leighton, 1961).

$$
\mathrm{NO}_{2}+h v \rightarrow \mathrm{NO}+\mathrm{O}
$$

* Work performed under the auspices of the U.S. Department of Energy.

$$
\begin{array}{r}
\mathrm{O}+\mathrm{O}_{2}+\mathrm{M} \rightarrow \mathrm{O}_{3}+\mathrm{M}, \\
\mathrm{NO}+\mathrm{O}_{3} \rightarrow \mathrm{NO}_{2}+\mathrm{O}_{2} .
\end{array}
$$

Assuming that $[\mathrm{NO}]$ is about $5 \mathrm{ppb}$ and $j\left(\mathrm{NO}_{2}\right)$ is $0.0013 \mathrm{~s}^{-1}$ (Harvey et al, 1977), the expected lag time between changes in the solar intensity and changes in $\left[\mathrm{O}_{3}\right]$ can be calculated from (Hampson and Garvin, 1978)

$$
\text { time }=\left(j\left(\mathrm{NO}_{2}\right)+k_{3}[\mathrm{NO}]+k_{3}\left[\mathrm{O}_{3}\right]\right)^{-1}
$$

Brackets denote concentration; $k_{3}(=2.1 \times$ $10^{-12} \exp -1450 / T \mathrm{~cm}^{3}$ molecule ${ }^{-1} \mathrm{~s}^{-1}$ ) (Hampson and Garvin, 1978) is the rate constant for Reaction (3); and $j\left(\mathrm{NO}_{2}\right)$ is the photolysis rate of $\mathrm{NO}_{2}$. The resulting lag time is about $150 \mathrm{~s}$ at the rapidly changing peak of the eclipse; this is consistent with the observed minima in Fig. 1, which are estimated to be less than two minutes apart. Lag times at the more gradual onset and end of the eclipse are thought to be the result of natural variations in the ambient $\left[\mathrm{O}_{3}\right]$.

\section{CONCLUSIONS}

The data collected during the eclipse show the labile behavior of ozone in the boundary layer; researchers who use ozone as an atmospheric tracer or who measure the ozone concentration downwind of pollution sources should be aware of the related implications regarding the effects of variable cloudiness on the concentration of ozone over the regional areas commonly used in these types of studies. The effects of cloudiness on photochemical reactions has been noted previously (Harvey et al., 1977; Jackson et al., 1975;

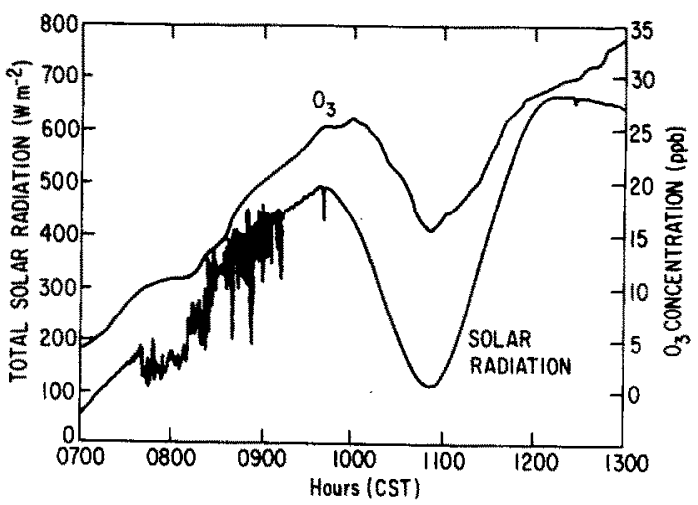

Fig. 1. Ozone concentration in ppb and total solar radiation in $\mathrm{W} \mathrm{m}^{-2}$ on 26 February 1979. 
Stedman et al., 1975), but this might be the first observation of changes in the ozone concentration resulting from a solar eclipse.

Acknowledgements - We thank the Argonne Center for Educational Affairs for providing funds for this research and the University of Michigan for the use of their ozone sensor.

Atmospheric Physics Section,

JOHN A. EASTMAN

Radiological and Environmental

Research Division,

Argonne National Laboratory,

Argonne, IL 60439, U.S.A.

Department of Chemistry.

University of Michigan,

Ann Arbor, MI 48109, U.S.A

\section{REFERENCES}

Davis D. D., Smith G. and Klauber G. (1974) Trace gas analysis of power plant plumes via aircraft measurement:

Donald H. Stedman
$\mathrm{O}_{3}, \mathrm{NO}_{x}$, and $\mathrm{SO}_{2}$ chemistry. Science. NY. 186, 733-736. Dimitriades B. (Ed.) (1977) Int. Conf. on Photochemical Oxidant Pollution and its Control. EPA Report No. EPA$600 / 3-77-001$

Hampson R. F. and Garvin D. (Eds) (1978) Reaction Rate Photochemical Data for Atmospheric Chemistry 1977. NBS Special Publication 513, March.

Harvey R. B., Stedman D. H. and Chameides W. (1977) Determination of the absolute rate of solar photolysis of $\mathrm{NO}_{2}$. J. Air Pollut. Control Ass. 27, 663-666.

Jackson J. O., Stedman D. H., Smith R. G., Hecker L. H. and Warner P. O. (1975) Direct $\mathrm{NO}_{2}$ photolysis rate monitor. Rev. scient. Instrum. 46, 376-378.

Leighton P. A. (1961) Photochemistry of Air Pollution. Academic Press, New York, pp. 152-157, 255-263.

Miller D. F., Alkezweeny A. J., Hales J. M. and Lee R. N (1978) Ozone formation related to power plant emissions Science, N.Y. 202, 1186-1188.

Stedman D. H., Chameides W. and Jackson J. O. (1975) Comparison of experimental and computed values for .$J\left(\mathrm{NO}_{2}\right)$. Geophys. Res. Lett. 2, 2225. 